\title{
RESEARCH PROPOSAL: EVALUATION OF ART IN ADULT PATIENTS
}

\author{
PROTOCOLO DE PESQUISA:AVALIAÇÃO DO TRATAMENTO RESTAURADOR \\ ATRAUMÁTICO EM PACIENTES ADULTOS
}

Régia Luzia ZANATA

DDS. MSc, PhD, Bauru Dental School, University of Sao Paulo, Bauru, Sao Paulo, Brazil.

Corresponding address: Dra. Régia L. Zanata - Faculdade de Odontologia de Bauru - Universidade de São Paulo - Alameda Octávio Pinheiro Brisolla 9-75 - Cep.: 17012-901, Bauru - São Paulo - UBAS - Setor Odontológico - Tel: + 551432358317 - e-mail: regiaz@usp.br

\begin{abstract}
$T_{\text {h }}$

he primary objective of the Atraumatic RestorativeTreatment (ART) is to reduce the indication of tooth extraction by means of a low-cost technique. Considering the difficulties of Brazilian public services to meet the demand of care of the low-income population, with lack of care to the adult population, which usually receives only emergency care, the aim of this study is to assess the performance of high-viscosity glass ionomer cements accomplished by the modified atraumatic restorative treatment in one- and multiple-surface cavities, compared to the conventional restorative approach. It will be analyzed the clinical performance of the materials; cost (material and human resources); patient satisfaction with the treatment received; and preventive effect of treatment.

Uniterms: Atraumatic Restorative Treatment; Glass ionomer cements; Normal pregnancy; Oral health.
\end{abstract}

\section{RESUMO}

objetivo primeiro do Tratamento Restaurador Atraumático (TRA) é reduzir a indicação de extrações dentárias através de uma técnica operatória de baixo custo. Considerando as dificuldades do Serviço de Saúde Pública do Brasil de suprir a demanda de serviço requerida pela população adulta de baixa renda, que usualmente recebe atendimento emergencial, o objetivo deste estudo é avaliar a performance clínica de um cimento de ionômero de vidro de alta viscosidade empregado através da técnica atraumática modificada em cavidades de uma e de múltiplas superfícies, comparativamente à abordagem restauradora convencional. Serão analisados a performance clínica dos materiais; o custo (material e recursos humanos); a satisfação do paciente com o tratamento recebido; e o impacto preventivo do tratamento.

Unitermos: Tratamento Restaurador Atraumático; Cimentos de ionômero de vidro; Gravidez normal; Saúde bucal.

\section{INTRODUCTION}

The data of the last and most complete national epidemiological oral health survey, recently published ${ }^{28}$, reveal that, even though Brazil has reached the goal of the World Health Organization (WHO) for the age of 12 years, the adolescent population (15 to 19 years) presents a high caries prevalence, with a DMFT (index that evaluates the caries experience by the number of decayed, missing or filled teeth) of 6.2, whereas the adult population, represented by the age range of 35 to 44 years, presents early tooth loss.

Table 1 displays the significant increase in DMFT for the age ranges evaluated and leads to a questioning on the type of dental care provided to the young adult population (age range 20 to 34 years, not evaluated in this survey), since among the adolescents there is predominance of the “decayed" component in the DMFT index (42\%), with $14 \%$ for the "missing" component, with a mean number of 0.2 tooth lost. This situation is changed in the adult age range, on which the "missing" component accounts for $66 \%$ of the index, with a mean number of 13 missing teeth, whereas the “decayed" component represents $12 \%$ of the index.

The first studies evaluating the ART approach were published ten years ago ${ }^{6,16}$. The technique has been improved by the development of high-viscosity cements ${ }^{3,15,17,18,24}$ and the number of studies has increased in recent years. Clinical investigations assure the good clinical performance of one-surface and multiple-surface ART restorations, 4,5,7-13,21-23,25,27. Recent studies have corroborated the arrest of caries and remineralization of the underlying affected enamel and dentin ${ }^{14,20}$ as well as inhibition of the levels and viability of cariogenic bacteria ${ }^{1,2}$. 
Considering that the primary objective of the atraumatic treatment is to reduce the indication of tooth extraction by means of a low-cost technique, and considering the difficulties of Brazilian public services to meet the demand of care of the low-income population, with lack of care to the adult population, which usually receives only emergency care, the aim of this study is to assess the performance of high-viscosity glass ionomer cements accomplished by the modified atraumatic restorative treatment in one- and multiple-surface cavities, compared to the conventional restorative approach, with analysis of the clinical performance of the materials; cost (material and human resources); patient satisfaction with the treatment received; and preventive effect of treatment.

Insertion of the atraumatic restorative treatment in oral health promotion programs targeted to pregnant women is particularly interesting, since the importance of the measures for prevention and control of caries and periodontal disease has been recently demonstrated in the literature.

Advanced stages of these diseases are frequent in lowincome pregnant women ${ }^{26}$, and immediate intervention is fundamental to assure the welfare of the patient and reduce the risk to the health of the fetus and future infant. However, during this period, even though there is no contraindication to the conventional treatment, the control of oral infections should be as less invasive as possible, since the utilization of medicines and stressing situations should be avoided whenever possible.

\section{MATERIALAND METHODS}

\section{Calculation of sample size}

On the basis of a mean number of 2,000 pregnant women/ year attending the 18 public health centers of the city of Bauru (city with nearly 300,000 inhabitants), and assuming a maximum error of 0.05 , it was calculated that 400 pregnant women, randomly selected at the public health centers according to the proportionality criterion, would be representative of the group under study. These patients will be clinically examined (DMFS index and white spot lesions) and will respond to a questionnaire on oral health knowledge and practices; satisfaction with oral health and its impact on the quality of life; level of information on the dental care during pregnancy; and socioeconomic variables.

\section{Inclusion criteria}

Patients presenting at most one cavity affecting more than one surface in posterior teeth (Class II with antagonist) and/or presenting proximal cavities in anterior teeth (Class III or IV), not receiving other type of dental care, with no medical contraindication and agreeing to participate after reading the information letter (Figure 1) will be selected for the study.

A parallel groups design will be employed; the patients will be randomly divided into two groups: ART and conventional (C) in the proportion of 2:1, respectively.

\section{Clinical procedure}

The ART group will be submitted to full-mouth caries excavation, with application of high-viscosity glass ionomer cement in all cavities. When needed, the access to the lesion will be achieved with aid of rotary instruments. Removal of softened dentin will be accomplished with a manual instrument. The material will be prepared and inserted following the manufacturer's instructions. After insertion of the material, the surface will be protected with varnish or nail enamel, followed by removal of excess material and occlusal adjustment.

In the control group (C), removal of decayed tissue will be performed with rotary instruments. Preparation will be conservatively performed, with no preventive extension. Restorations in posterior teeth will be filled with non-gamma 2 amalgam, and restorations in anterior teeth will be filled with composite resin. Restorations will be polished in a later session.

In both groups restorative procedures will be performed by two experienced dentists, in a mobile dental unit, under isolation with cotton rolls and suction.

All patients selected will receive oral hygiene instructions and will receive toothbrush, toothpaste and dental floss. When indicated, dental scaling and polishing will also be performed.

Patients in need of emergency care (medicines, drainages, endodontic dressings and tooth extractions) will be referred to the public health centers for accomplishment of such procedures.

\section{Evaluations}

After 12 and 36 months, the restorations will be clinically evaluated as to their anatomical shape, marginal integrity, color, surface texture, marginal discoloration and presence of caries at the restoration margins according to the USPHS criteria $^{19}$. Restorations will be regarded as successful if

TABLE 1- Caries prevalence and DMFT index recorded at the National Oral Health - SB 2000, Brazil / 2003

12 years

2.8

DMFT

decayed

$58 \%(1.6)$

missing

Caries Prevalence
15 to 19years

6.2

$42 \%(2.6)$

$14 \%$

$90 \%$
35 to $44 y$

20.1

$12 \%(2.3)$

66\%

$99.5 \%$ 
scored by Alpha and Bravo codes in qualitative categories of the USPHS index.

Evaluations will be performed by 2 examiners, not working as operators and previously calibrated (intra and interexaminer kappa). Restorations will be photographed at baseline and in the subsequent evaluations.

Comparisons will be performed between the materials (amalgam x ART for Class I and II cavities; composite resin x ART for Class III, IV and V cavities); between the types of cavities; and between operators, by means of the chi-square or Fisher test.

The cumulative survival rate will be calculated using the life table.

The preventive effect will be analyzed by comparison of the mean caries increase of the patients in both groups $(t$ test) and according to the presence and severity of the disease in their children (chi-square and t test).

The cost-benefit relationship will be also analyzed, according to the time spent for accomplishment of the restorative procedures (mean time per restoration of each operator), number of sessions, costs with consumption and permanent materials, and satisfaction of the patient with the treatment received (Figure 2).

\section{Budget}

Calculation of the budget comprised the permanent material (instruments), restorative materials, consumption materials for preventive procedures, individual protective equipment and biosecurity, office material, transportation of the mobile unit, financial aid for the patients, mail expenses, and donations of toothpaste, toothbrush and dental floss.

- 10 kits for ART containing:

- pliers, dental probe, dental mirror, excavators, Hollenback, scissors, glass slab, spatula n. 24, matrix retainer (U\$ 680.00)

- consumption (restorative) material (U\$ 1,000.00)

- 10 kits for conventional care (amalgam and composite resin) (U\$ 975.00) containing:

- burs, diamond burs, cutting instruments, condensers, burnishers, applicators, matrix retainer (U\$ 975.00)

- consumption (restorative) material (U\$ 588.00)

- 10 kits for periodontal procedures:

- Millimeter probe, Gracey curettes (U\$ 234.00)

- consumption material for preventive procedures, individual protective equipment / biosecurity, office material (U\$587.00)

- transportation of the mobile unit (U\$ 300.00)

- financial aid (U\$ 1000.00 )

- donation of toothpaste, toothbrush and dental floss (U\$ 800.00)

- mail expenses (U\$ 100.00)

- Total (U\$ 6 267.00)

\section{FIGURE 1- Information letter}

\section{- Information letter}

Dear patient

- Dental treatment during pregnancy is safe, benefits you and supplements prenatal care.

- You will receive very useful information as to feeding and care with your teeth and your child's teeth. You will respond to questions on socioeconomic status and oral health practices. Your mouth will be examined and in case there are large cavities, which are the object of the present study, you will be selected to participate in the study.

- If selected, you will receive tooth cleaning (prophylaxis). Basic treatment for gingival problems (scaling) will be offered if need.

- The investigation will comprise two study groups; in one group, caries will be treated by the conventional technique, and the other group will be treated by a new technique that removes just the softened caries with no need of anesthesia or handpieces in most instances, which hinders further destruction of the teeth. You will be randomly assigned to any group. - Restorations will be evaluated after 1 and 3 years. Your child's teeth will be evaluated at each examination to check for the presence of caries. You will receive financial aid to attend the evaluations.

- Oral health problems that may not be solved in the present study will be referred to dental clinics of the public health centers of the city or to reference centers, according to each case. Restorations failing during the study will be repaired or replaced. Some instances will be photographically recorded, yet the photos will only display the mouth and teeth of the patient, with no possibility of identification.

- All records related to this study will be exclusively employed for scientific or academic purposes. Secrecy is assured to the patients.

Informed consent term

By the present instrument that meets the guidelines and regulations of investigations, Misses , ID number , after careful reading of the information letter properly explained by the professionals, aware of the procedures that will be performed in the present study and having no doubts as to what has been read and explained, signs the present informed consent term agreeing with participation in the study.

The patient or her legal representative may quit participating in the study at any time.

In witness thereof the present term is hereby signed 


\section{Timeline}

The timeline was based on a previous study conducted in a group with similar characteristics ${ }^{26,27}$. It was assumed that $30 \%$ of the patients examined will meet the inclusion criteria.

- selection, application of questionnaire and clinical examination of the sample (400 patients) - 3 months

- educational / preventive procedures (120 patients)

$\cdot 1 \mathrm{~h} /$ patient $=120 \mathrm{~h}=1,5$ months

- Restorative procedures (120 patients)

- 2 operators $/ 20 \mathrm{~h}$ per week $=80 \mathrm{~h}$ per month

- 9 decayed teeth per patient / 30min per restoration

. 9 × $120 \times 0.5=540 \mathrm{~h} / 80=.7$ months

- Total $=12$ months of intervention

\section{REFERENCES}

1- Bonecker M, Grossman E, Cleaton-Jones PE, Parak R. Clinical, histological and microbiological study of hand-excavated carious dentine in extracted permanent teeth. SADJ 2003;58(7):273-8.

2- Carvalho CK, Bezerra AC. Microbiological assessment of saliva from children subsequent to atraumatic restorative treatment (ART). Int J Paediatr Dent. 2003; 13(3):186-92.

3- Ewoldsen N, Covey D, Lavin M. The physical and adhesive properties of dental cements used for atraumatic restorative treatment. Spec Care Dentist. 1997;17(1):19-24.

4- Frencken JE, Van 't Hof MA, Van Amerongen WE, Holmgren CJ. Effectiveness of single-surface ART restorations in the permanent dentition: a meta-analysis. J Dent Res. 2004;83(2):120-3.

5- Frencken JE, Makoni F, Sithole WD. ART restorations and glass ionomer sealants in Zimbabwe: survival after 3 years. Community Dent Oral Epidemiol. 1998;26(6):372-81.

FIGURE 2- Questionnaire regarding the dental treatment received

Patient

Group

Teeth submitted to treatment:

Questionnaire

After accomplishment of dental treatment, did you:

1. Have to look for the dentist? ( ) Yes ( ) No

2. Why?

a. ( ) Toothache. Which tooth?

b. ( ) Presence of cavity

c. ( ) Broken tooth or restoration. Which tooth?

d. ( ) Problems with the gums

e. ( ) Joint pain

f. ( ) Prevention / Follow-up

3. Did you visit a private dentist or a dentist in a public health center?

4. Did you have any tooth extracted?

Which?

5. Did you have problems with the gums?

a. ( ) bleeding

b. ( ) pain

c. ( ) tooth mobility

6. Do you currently have any of these problems:

a. ( ) difficulty to speak some words?

b. ( ) difficulty to chew some foods?

c. ( ) need to interrupt a meal due to toothache?

d. ( ) need to avoid some foods due to toothache?

e. ( ) avoids smiling because of the appearance of your teeth?

f. ( ) feel annoyed with your teeth?

g. ( ) had any difficulty to get a job because of your teeth?

h. ( ) had any other type of difficulty in relationship with other people due to your teeth? Explain:

7. With regard to the restorative treatment received:

a. ( ) excellent

b. ( ) good

c. ( ) regular

d. ( ) bad

Why? 
6- Frencken JE, Pilot T, Songpaisan Y, Phantumvanit P. Atraumatic restorative treatment (ART): rationale, technique, and development. J Public Health Dent. 1996;56(sp. Issue):135-40.

7- Ho TF, Smales RJ, Fang DT. A 2-year clinical study of two glass ionomer cements used in the atraumatic restorative treatment (ART) technique. Community Dent Oral Epidemiol. 1999;27(3):195-201.

8- Kalf-Scholte SM, van Amerongen WE, Smith AJ, van Haastrecht HJ. Atraumatic restorative treatment (ART): a three-year clinical study in Malawi-comparison of conventional amalgam and ART restorations. J Public Health Dent. 2003;63(2):99-103.

9- Lo EC, Luo Y, Fan MW, Wei SH. Clinical investigation of two glass-ionomer restoratives used with the atraumatic restorative treatment approach in China: two-years results. Caries Res. 2001;35(6):458-63.

10- Lo EC, Holmgren CJ. Provision of Atraumatic Restorative Treatment (ART) restorations to Chinese pre-school children-a 30-month evaluation. Int J Paediatr Dent. 2001;11(1):3-10.

11- Luo Y, Wei SH, Fan MW, Lo EC. Clinical investigation of a highstrength glass ionomer restorative used with the ART technique in Wuhan, China: one-year results. Chin J Dent Res. 1999;2(3-4):73-8.

12- Mandari GJ, Frencken JE, van't Hof MA. Six-year success rates of occlusal amalgam and glass-ionomer restorations placed using three minimal intervention approaches. Caries Res. 2003;37(4):246-53.

13- Mandari GJ, Truin GJ, van’t Hof MA, Frencken JE. Effectiveness of three minimal intervention approaches for managing dental caries: survival of restorations after 2 years. Caries Res. 2001;35(2):90-4.

14- Massara ML, Alves JB, Brandao PR. Atraumatic restorative treatment: clinical, ultrastructural and chemical analysis. Caries Res. 2002; 36(6):430-6

15- Palma-Dibb RG, Castro CG de, Ramos RP, Chimello DT, Chinelatt MA. Bond strength of glass-ionomer cements to caries-affected dentin. J Adhes Dent. 2003;5(1):57-62.

16- Phantumvanit P, Songpaisan Y, Pilot T, Frencken JE. Atraumatic restorative treatment (ART): a three-year community field trial in Thailand-survival of one-surface restorations in the permanent dentition. J Public Health Dent. 1996;56(sp Issue):141-5.

17- Platt JA, Rhodes B. Microleakage of high-strength glass ionomer and resin composite restorations in minimally invasive treatment. J Indiana Dent Assoc. 2001-2002;80(4):20-2.

18- Pereira LC, Nunes MC, Dibb RG, Powers JM, Roulet JF, Navarro MF. Mechanical properties and bond strength of glass-ionomer cements. J Adhes Dent. 2002;4(1):73-80.

19- Hyge G, Snyder M. Evaluating the clinical quality of restorations. J Am Dent Assoc. 1973;87:369-77.

20- Smales RJ, Gao W. In vitro caries inhibition at the enamel margins of glass ionomer restoratives developed for the ART approach. J Dent. 2000;28(4):249-56.

21- Souza EM et al. Clinical evaluation of the ART technique using high density and resin modified glass ionomer cements. Oral Health Prev Dent. 2003;1(3):201-7.

22- Taifour D, Frencken JE, Beiruti N, van't Hof MA, Truin GJ, van Palenstein Helderman WH. Comparison between restorations in the permanent dentition produced by hand and rotary instrumentationsurvival after 3 years. Community Dent Oral Epidemiol. 2003;31(2):122-8.
23- Taifour D, Frencken JE, Beiruti N, van 't Hof MA, Truin GJ. Effectiveness of glass-ionomer (ART) and amalgam restorations in the deciduous dentition: results after 3 years. Caries Res. 2002;36(6):437-44.

24- Yap AU, Pek YS, Cheang P. Physico-mechanical properties of a fast-set highly viscous GIC restorative. J Oral Rehabil. 2003;30(1):1-

25- Yu C, Gao XJ, Deng DM, Yip HK, Smales RJ. Survival of glass ionomer restorations placed in primary molars using atraumatic restorative treatment (ART) and conventional cavity preparations: 2-year results. Int Dent J. 2004;54(1):42-6.

26- Zanata RL, Navarro MF, Pereira JC, Franco EB, Lauris JR, Barbosa $\mathrm{SH}$. Effect of caries preventive measures directed to expectant mothers on caries experience in their children. Braz Dent J. 2003;14(2):75-81.

27- Zanata RL, Navarro MF, Barbosa SH, Lauris JR, Franco EB. Clinical evaluation of three restorative materials applied in a minimal intervention caries treatment approach. J Public Health Dent. 2003;63(4):221-6.

28- www.ministeriodasaude.gov.br/sb2000 